\title{
BLENDED LEARNING, MODEL PEMBELAJARAN ABAD ke-21 DI PERGURUAN TINGGI
}

\author{
Milya Sari \\ Fakultas Tarbiyah dan Keguruan IAIN Imam Bonjol Padang \\ Korespondensi: Jl. Green Bariang Indah III/E Anduring Padang, Sumatera Barat \\ E.mail: milyasari.iain@gmail.com
}

\begin{abstract}
The rapid progress of information and communication technology in the $21 t^{h}$ century forced teachers who teach students at any levels of education to change their behaviour and mind-set, even the the commitee that supported them to achieve their teaching objective. A good approach is that a way in which one could integrate technology and education, that was through Blended Learning Model (BLM). This model combined the usual teaching classroom and teaching online. The strength of this model was that this could increase the interaction among the students whenever and wherever.
\end{abstract}

Kata kunci: Model Blended Learning, TIK, pembelajaran abad 21

\section{PENDAHULUAN}

$\mathrm{T}$ eknologi Informasi dan Komunikasi selanjutnya disingkat TIK menjadi bagian yang tak terpisahkan dalam kehidupan. Teknologi seperti ponsel dan jaringan sosial daring (online) seperti Facebook dan twitter telah mengubah secara revolusioner cara manusia berkomunikasi. Mesin pencari internet seperti Google dan Yahoo juga telah mengubah secara revolusioner cara manusia mencari informasi. Sehingga Eggen dan Kauchak (2012: 27) mengemukakan bahwa melek (literasi) teknologi telah menjadi keahlian dasar yang penting setelah membaca, menulis dan berhitung.

Pengaruh TIK sangat besar kepada peserta didik. Teknologi adalah sesuatu yang ingin dikuasai peserta didik. Mereka menggunakan internet, ponsel dan mengirim SMS seperti makanan sehari-hari. Banyak peserta didik sudah menggunakan media sosial
Facebook dan twitter. Artinya peserta didik sekarang sangat melek teknologi, namun tidak demikian dengan gurunya. Akibatnya, terjadi kesenjangan antara peserta didik dan pendidik yang tidak menggunakan teknologi di ruang kelas mereka. Pendekatan yang baik adalah mengintegrasikan teknologi dengan pendidikan dan menghilangkan segala kesenjangan yang ada. Dengan mengenali minat peserta didik dan memanfaatkan minat-minat itu, hubungan pendidikpeserta didik dapat meningkat.

Pada era TIK seperti sekarang, peserta didik yang akan dihadapi adalah peserta didik yang lahir dan berkembang di era digital, maka suka tidak suka, mau tidak mau guru pun harus memiliki literasi teknologi yang tinggi. Lembaga Pendidikan Tenaga Keguruan (LPTK) sebagai lemabaga penghasil calon pendidik/guru perlu membekali guru dan calon guru untuk terampil menggunakan teknologi terutama TIK, karena tantangan guru masa depan berkaitan 
dengan TIK. Eggen dan Kauchak (2012: 27-28) menegaskan bahwa standar untuk sekolah abad 21 atau abad digital untuk guru dan siswa berkaitan dengan penerapan teknologi dalam pembelajaran. Guru harus bisa mempersiapkan siswanya untuk hidup di abad digital, salah satunya menggunakan pengetahuan mereka tentang materi pelajaran, pembelajaran dan teknologi untuk memfasilitasi pengalaman yang dipelajari siswa tingkat lanjut, kreativitas, dan inovasi dalam situasi tatap muka dan virtual. Salah satu cara yang dapat dilakukan guru/dosen untuk peningkatan layanan dalam situasi tatap muka dan virtual (online) melalui Model Blended Learning, yang selanjutnya disingkat dengan MBL.

\section{MODEL BLENDED LEARNING}

\section{Pengertian}

Model adalah bentuk atau contoh yang tersusun secara sistematis. Pembelajaran adalah pengaturan lingkungan yang terdapat proses interaksi untuk memperoleh sesuatu. Model pembelajaran adalah pendekatan spesifik dalam mengajar (Eggen dan Kauchak, 2012:7) dan mengandung unsur-unsur instruksional seperti film, buku, program, kurikulum (Dewey dalam Joyce \& Weil (1992:4). Model pembelajaran juga mengajarkan bagaimana cara belajar (Trianto, 2009:74). Model pembelajaran adalah bentuk atau desain spesifik yang dirancang secara sistematis berdasarkan teori belajar atau landasan pemikiran bagaimana mahasiswa belajar untuk mencapai tujuan pembelajaran. Memiliki pengaturan lingkungan belajar, adanya proses interaksi, yang digunakan untuk membantu mahasiswa memperoleh hasil belajar lebih baik. Komponen model terdiri dari sintak, sistem sosial, prinsip reaksi, sistem pendukung dan dampak instruksional dan dampak pengiring.
Kelima komponen ini akan digunakan untuk merekonstruksi pengembangan atau penciptaan suatu model pembelajaran.

Secara sederhana Blended Learning bermakna pola pembelajaran yang mengandung unsur pencampuran, atau penggabungan antara satu pola pembelajaran dengan pola pembelajaran yang lainnya. Blended learning merupakan salah satu isu pendidikan terbaru dalam perkembangan globalisasi dan teknologi. Banyak institusi atau praktisi yang telah mengembangkan dan memberikan definisi dengan bahasa mereka sendiri, sesuai dengan tipologi praktek blended learning" itu sendiri.

Definisi blended learning menurut Driscoll (2002) merujuk pada empat konsep yang berbeda yaitu:

a) Blended learning merupakan pembelajaran yang mengkombinasikan atau menggabungkan berbagai teknologi berbasis web, untuk mencapai tujuan pendidikan.

b) Blended learning merupakan kombinasi dari berbagai pendekatan pembelajaran (seperti behaviorisme, konstruktivisme, kognitivisme) untuk menghasilkan suatu pencapaian pembelajaran yang optimal dengan atau tanpa teknologi pembelajaran.

c) Blended learning juga merupakan kombinasi banyak format teknologi pembelajaran, seperti video tape, CD-ROM, web-based training, film) dengan pembelajaran tatap muka.

d) Blended learning menggabungkan teknologi pembelajaran dengan perintah tugas kerja aktual untuk menciptakan pengaruh yang baik pada pembelajaran dan pekerjaan.

Graham (2005: 4) menyebutkan definisi Blended learning yang paling sering dikemukakan, adalah: 
a) defenisi yang mengkombinasikan berbagai modalitas media pembelajaran,

b) defenisi yang mengkombinasikan berbagai metode-metode pembelajaran, teori belajar, dan dimensi pedagogis;

c) defenisi yang mengkombinasikan antara pembelajaran online dengan face-to-face (pembelajaran tatap muka).

Berdasarkan pengelompokan dan definisi yang telah dijelaskan di atas maka MBL dalam tulisan ini berdasarkan definisi ke 3 (tiga) dari Driscoll dan Graham yaitu; kombinasi karakteristik pembelajaran tradisional dan pembelajaran elektronik atau e-learning. MBL adalah kegiatan pembelajaran yang menggabungkan kegiatan belajar tatap muka dengan kegiatan belajar online dari aspek teori belajar, pendekatan, serta model pembelajaran untuk mencapai tujuan pembelajaran.

\section{Kelebihan Model Blended Learning}

MBL muncul sebagai jawaban terhadap kelemahan pembelajaran tatap muka dan pembelajaran online. Namun masing-masing pembelajaran ini juga memiliki kelebihan-kelebihan. Kelebihan perkuliahan tatap muka yang utama adalah terjadinya interaksi langsung antara pendidik dengan peserta didik dan perserta didik dengan peserta didk lainnya. Interaksi ini membuat terjadinya perasaan lebih kuat terhubung ke instruktur/dosen. Kelemahan pembelajaran tatap muka adalah proses pembelajaran yang terjadi dibatasi oleh ruang dan waktu sehingga pembelajaran dirasakan kurang maksimal oleh pendidik.

Kelebihan pembelajaran online berbasis web menurut Rusman (2011: 271-275) adalah:

(1) memungkinkan setiap orang mempelajari apa pun tanpa dibatasi ruang dan waktu, karena akses tersedia kapan pun, dimana pun di seluruh dunia;

(2) biaya operasional setiap siswa untuk mengikuti kegiatan pembelajaran menjadi lebih terjangkau;

(3) pengawasan terhadap perkembangan siswa jadi lebih mudah;

(4) rancangan pembelajaran berbasis web memungkinkan dilakukannya kegiatan pembelajaran yang sudah terpersonalisasi;

(5) materi pembelajaran bisa diperbaharui secara lebih mudah.

Namun demikian pembelajaran berbasis web juga mempunyai kekurangan, yaitu:

(1) keberhasilan pembelajaran berbasis web bergantung pada kemampuan dan motivasi pembelajaran;

(2) akses untuk mengikuti pembelajaran dengan menggunakan web seringkali menjadi masalah bagi pembelajar;

(3) pembelajar cepat merasa bosan dan jenuh jika mereka tidak mengakses informasi, dikarenakan tidak terdapatnya peralatan yang memadai dan bandwith yang cukup;

(4) dibutuhkan panduan bagi pembelajar untuk mencari informasi yang relevan, karena informasi yang terdapat di dalam web sangat beragam;

(5) dengan menggunakan pembelajaran berbasis web, pembelajaran terganggu jika terdapat keterbatasan dalam fasilitas komunikasi.

(6) Satu kelemahan terbesar dalam pembelajaran online adalah amat kurangnya interaksi langsung antara pendidik dengan peserta didik maupun antara sesama peserta didik. 
MBL merupakan pembelajaran yang memadukan kelebihan perkuliahan tatap muka dan kelebihan pembelajaran online. MBL dapat menciptakan lingkungan belajar yang positif untuk terjadinya interaksi antara sesama peserta didik, dan peserta didik dengan pendidiknya tanpa dibatasi oleh ruang dan waktu. Dewey (1938) dan Moore dalam Comey (2009: 9), mengemukakan bahwa interaksi antar siswa dan interaksi antara siswa dan guru merupakan faktor kunci dalam proses belajar siswa dan merupakan elemen penting dalam menciptakan pengalaman belajar yang efektif. Menurut Moore dalam Comey (2009:9-10) ada tiga tipe interaksi, yaitu learner-content interaction, learner instructor interaction, and learnerlearner interaction, serta learner interface interaction. Graham (2005:5) menggambarkan empat dimensi kritis interaksi yang terjadi antar kelas tatap muka dan kelas online, seperti terlihat pada gambar 1 . berikut ini.

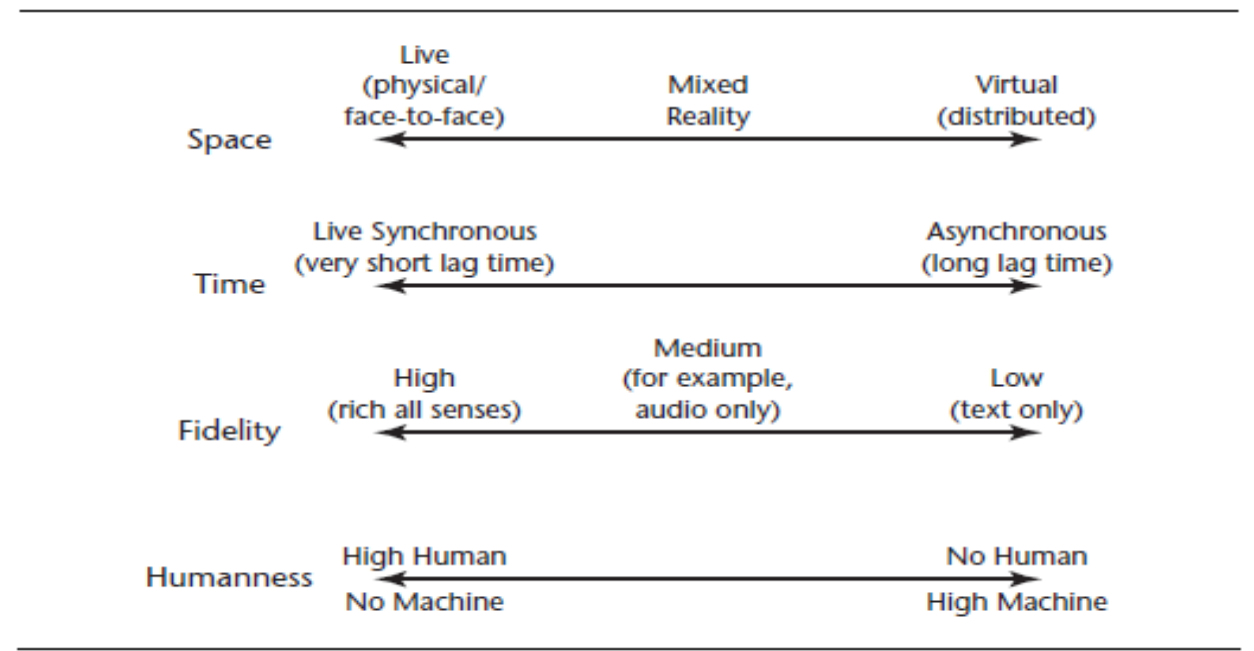

Gambar 1. Suatu kontinum empat dimensi kritis interaksi yang terjadi dalam lingkungan kelas tatap muka dan online (virtual).

Banyak interaksi yang terjadi dalam MBL. Interaksi bisa terjadi pada pengajaran secara 'synchronously' (pada waktu yang sama) ataupun 'asynchronously' (pada waktu yang berbeda). Dalam MBL, materi pengajaran disiapkan pendidik untuk bisa diakses siswa secara online melalui media yang mempunyai teks, grafik, animasi, simulasi, audio dan video. Pendidik juga menyediakan kemudahan untuk 'discussion group' sehingga terjadi interaksi antar peserta didik, peserta didik dan pendidik kapan saja dan dimana saja secara lisan maupun tulisan.

Eggen \& Kauchak (2012:57-58) mengemukakan bahwa "semakin banyak peserta didik/siswa berlatih menggunakan bahasa, semakin dalam pemahaman mereka. Karena jika guru atau dosen yang berbicara atau menjelaskan, siswa/mahasiswa mungkin memahami mungkin tidak, tetapi jika mahasiswa yang mengatakannya, kemungkinan besar mereka memang akan "memahaminya". Seperti yang dikemukakan Silberman (2006: 23) "orang cenderung lupa tentang apa yang mereka dengar, tetapi yang saya ajarkan kepada orang lain, saya kuasai". Seperti kerucut pengalaman belajar yang diperkenalkan oleh Edgar Dale yang terlihat pada gambar 2. 


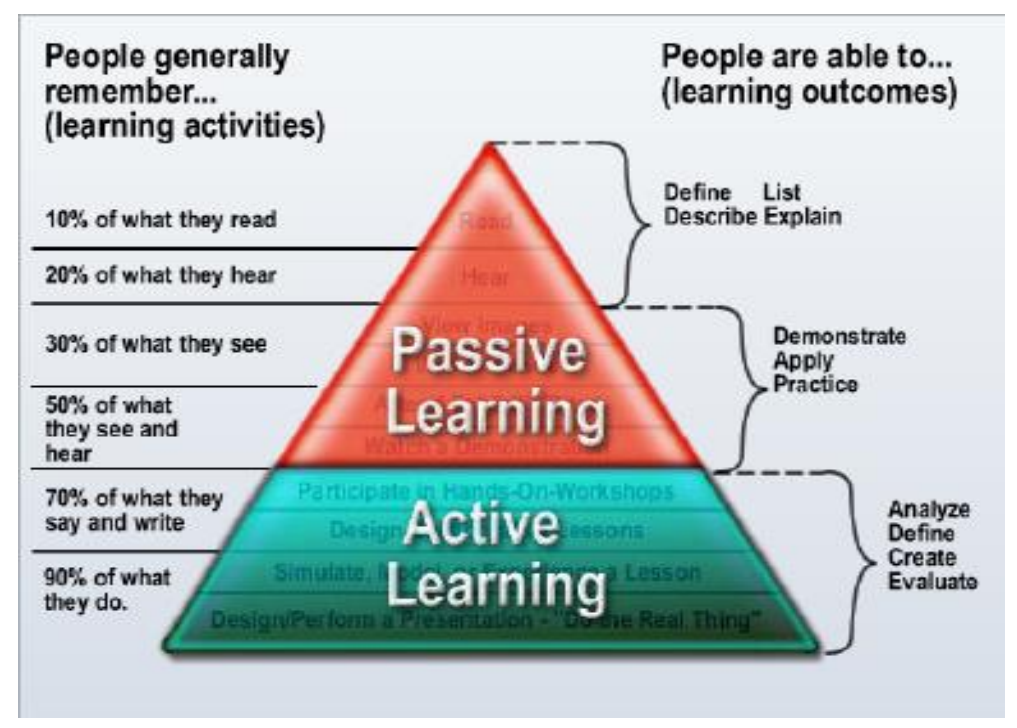

Gambar. 2. Kerucut pengalaman belajar dari Edgar Dale.

Tingkatan pengalaman peserta didik pada Gambar 2. bisa dikatakan bahwa orang-orang ingat: $10 \%$ dari apa yang mereka baca; $20 \%$ dari apa yang mereka dengar; $30 \%$ dari apa yang mereka lihat; $50 \%$ dari apa yang mereka lihat dan dengar $70 \%$ dari apa yang mereka tulis dan katakan; $90 \%$ dari apa yang mereka katakan seperti yang mereka lakukan. Sampai ke tingkat saya lihat dan saya dengar masih tergolong pembelajaran pasif, sedangkan saya katakan dan saya tulis sudah termasuk pembelajaran aktif.

Interaksi belajar merupakan faktor penting dalam pembelajaran. Interaksi dalam MBL termasuk pembelajaran aktif dan komunikasi bisa terjadi melalui lisan maupun tulisan. Hasil penelitian di Amerika menunjukkan MBL sangat efektif, dibandingkan dengan pembelajaran lain, MBL 30\% lebih baik, $40 \%$ waktu lebih singkat, dan $30 \%$ biaya lebih murah (Wawan Wardiana dalam Rusman et al, 2011: 249). Comey (2009: iv) juga menguji bagaimana persepsi mahasiswa terhadap lingkungan kelas yang berbeda antara program tatap muka, online, dan metoda blended, hasil penelitian menunjukkan bahwa dengan menggabungkan unsur-unsur kuliah tatap muka dan kuliah online, metoda blended dapat menciptakan lingkungan belajar yang positif, bisa menyediakan beberapa kenyamanan dari kuliah online tanpa menghilangkan kontak tatap muka yang banyak diinginkan mahasiswa. Kelas blended juga memberikan suasana yang lebih baik dari kelas tatap muka dan kelas online dalam menghasilkan tingkat partisipasi yang lebih tinggi dari mahasiswa dan perasaan lebih kuat terhubung ke instruktur/dosen.

Jadi MBL mampu memberikan interaksi antar mahasiswa dan mahasiswa dengan dosen yang lebih baik. Interaksi dapat terjadi melalui banyak kesempatan, yaitu kelas tatap muka dan kelas online. Mahasiswa yang mungkin malu berbicara atau mengajukan pertanyaan di ruang kelas tatap muka dapat memanfaatkan komunikasi online untuk berinteraksi dengan dosen maupun dengan temannya kapan pun dan dimana pun. Hal ini memberikan gambaran pentingnya interaksi sosial dan penggunaan bahasa lisan maupun tulisan dalam mendorong pembelajaran.

\section{Model-model Blended Learning}

TIK memiliki potensi untuk memperbaiki efektifitas pembelajaran. 
Akses terhadap sumber belajar melalui internet memberikan kesempatan kepada mahasiswa yang semula di luar jangkauan untuk memperoleh informasi lebih luas. MBL merupakan cara baru untuk meningkatkan proses belajar dan pembelajaran di perguruan tinggi. Graham (2005: 8-10) dan Sukarno (...: 3) menyatakan tiga alasan utama mengapa MBL dipilih di perguruan tinggi antara lain karena: peningkatan pedagogi; peningkatan akses dan fleksibilitas; dan peningkatan efektivitas biaya. Sedangkan Osguthorpe dan Graham dalam Graham (2005: 8) mengidentifikasi enam alasan menggunakan MBL: (1) kaya akan pengajaran, (2) akses ke pengetahuan, (3) interaksi sosial, (4) personal lembaga, (5) efektivitas biaya, dan (6) kemudahan revisi.

MBL dikembangkan oleh berbagai institusi sesuai dengan tujuan yang diinginkan. Graham (2005:10-11) menjelaskan bahwa semua MBL bisa terjadi pada level aktivitas, level perkuliahan, level program, atau level institusional. Dari empat level, kegiatan $M B L$ pada guru, dosen dan instruktur lebih mungkin dalam level aktivitas dan perkuliahan. Model-model blended learning yang dikembangkan di lembaga-lembaga pendidikan diantaranya terlihat pada Tabel 1. berikut ini:

Tabel 1. Model-model blended learning

\begin{tabular}{|c|c|c|}
\hline No & Model & Deskripsi \\
\hline \multirow{5}{*}{1} & \multicolumn{2}{|c|}{ Horn \& Staker (2011: 4-15) } \\
\hline & Model 1: Rotation & $\begin{array}{l}\text { Bentuk umum model rotasi adalah dalam kuliah yang diberikan } \\
\text { selama satu semester, siswa kembali pada jadwal tetap antara } \\
\text { pembelajaran online, belajar sendiri-sendiri/mandiri dan pem- } \\
\text { belajaran tatap muka tradisional dengan guru. Ini model BL yang } \\
\text { paling banyak dilakukan antara pembelajaran tatap muka dan } \\
\text { pembelajaran online. Guru biasanya mengawasi kerja online. }\end{array}$ \\
\hline & $\begin{array}{l}\text { Model 2: } \\
\text { Flex }\end{array}$ & $\begin{array}{l}\text { Program dengan model pembelajaran online yang fleksibel. } \\
\text { Pengajar memberikan dukungan yang fleksibel sesuai dengan } \\
\text { kebutuhan personal melalui tutorial dan sesi kelompok kecil. } \\
\text { Program ini cocok untuk perbaikan dropout dan perbaikan kredit } \\
\text { semester. }\end{array}$ \\
\hline & $\begin{array}{l}\text { Model } 3: \\
\text { Self-Blend }\end{array}$ & $\begin{array}{l}\text { Pembelajaran online merupakan sebagian kecil dari kegiatan } \\
\text { pembelajaran. Peserta didik memilih sendiri bentuk kursus online } \\
\text { untuk melengkapi pembelajaran tatap muka. Pembelajaran online } \\
\text { hanya sebagai pelengkap. }\end{array}$ \\
\hline & $\begin{array}{l}\text { Model 4: Enriched- } \\
\text { Virtual }\end{array}$ & $\begin{array}{l}\text { Merupakan pengembangan dari sekolah yang sepenuhnya online, } \\
\text { kemudian mengembangkan program blended untuk memberikan } \\
\text { siswa pengalaman sekolah tatap muka. Waktu pembelajaran } \\
\text { dibagi antara menghadiri kuliah di kampus dan pembelajaran jarak } \\
\text { jauh. Pada Model-Enriched Virtual, siswa jarang menghadiri } \\
\text { kuliah di kampus setiap hari. Ini berbeda dari model Self-Blend } \\
\text { karena merupakan pengalaman seluruh sekolah, tatap muka hanya } \\
\text { sebagai suplemen. }\end{array}$ \\
\hline \multirow{3}{*}{2} & \multicolumn{2}{|c|}{$\begin{array}{l}\text { Haughey (1998 dalam Rusman, 2011:251): pengembangan sisitem pengajaran } \\
\text { berbasis internet }\end{array}$} \\
\hline & Web course & $\begin{array}{l}\text { penggunaan Internet untuk keperluan pendidikan, yang mana } \\
\text { peserta didik dan pengajar sepenuhnya terpisah dan tidak } \\
\text { diperlukan adanya tatap muka. Seluruh bahan ajar, diskusi, } \\
\text { konsultasi, penugasan, latihan, ujian, dan kegiatan pembelajaran } \\
\text { lainnya sepenuhnya disampaikan melalui Internet. }\end{array}$ \\
\hline & Web centric course & $\begin{array}{l}\text { penggunaan Internet yang memadukan antara belajar jarak jauh } \\
\text { dan tatap muka (konvensional). Sebagian materi disampaikan } \\
\text { melalui Internet, dan sebagian lagi melalui tatap muka. Fungsinya }\end{array}$ \\
\hline
\end{tabular}




\begin{tabular}{|c|c|c|}
\hline & \multicolumn{2}{|r|}{ saling melengkapi. } \\
\hline & $\begin{array}{l}\text { web enhanced } \\
\text { course }\end{array}$ & $\begin{array}{l}\text { pemanfaatan Internet untuk menunjang peningkatan kualitas } \\
\text { pembelajaran yang dilakukan di kelas. Fungsi Internet adalah } \\
\text { untuk memberikan pengayaan dan komunikasi antara peserta } \\
\text { didik dengan pengajar, sesama peserta didik, anggota kelompok, } \\
\text { atau peserta didik dengan nara sumber lain. }\end{array}$ \\
\hline \multirow{6}{*}{3} & \multicolumn{2}{|c|}{$\begin{array}{l}\text { Harmon dan Jones dalam Rusman (2011: 252-253): level penggunaan ICT dalam } \\
\text { pembelajaran }\end{array}$} \\
\hline & $\begin{array}{l}\text { Level-1 } \\
\text { information }\end{array}$ & $\begin{array}{l}\text { pada level ini bahan-bahan pembelajaran tidak terlalu banyak } \\
\text { disajikan melalui ICT, tetapi terbatas pada bahan yang sifatnya } \\
\text { informeso untuk menunjang proses perkuliahan bahkan cenderung } \\
\text { bersifat admistratif dan aturan perkuliahan. }\end{array}$ \\
\hline & $\begin{array}{l}\text { Level-2 } \\
\text { supplemental }\end{array}$ & $\begin{array}{l}\text { pada level ini sudah mulai memasukkan bahan } \\
\text { perkuliahan/pembelajaran, namun sifatnya masih terbatas, belum } \\
\text { menguraikan isi pembelajaran secara lengkap, materi yang } \\
\text { disajikan masih pokok-pokoknya saja. }\end{array}$ \\
\hline & Level-3 Essensial & $\begin{array}{l}\text { dalam level ini hampir semua materi pembelajaran disediakan } \\
\text { dalam web. aktivitas guru-peserta didik tidak akan berjalan baik } \\
\text { jika tidak menggunakan fasilitas web. }\end{array}$ \\
\hline & Level-4 communal & $\begin{array}{l}\text { pada level ini mengkombinasikan pola tatap muka di kelas atau } \\
\text { penggunaan web secara online. Penyajian bahan pembelajaran } \\
\text { disajikan melalui cara langsung di kelas dan disajikan online. }\end{array}$ \\
\hline & Level-5 immersive & $\begin{array}{l}\text { pada level ini pembelajaran dilangsungkan secara virtual. Seluruh } \\
\text { isi materi pembelajaran disajikan secara online }\end{array}$ \\
\hline
\end{tabular}

\section{PEMBELAJARAN ABAD 21}

Pesatnya arus globalisasi serta perkembangan TIK saat ini menuntut perubahan sikap dan pola pikir guru/dosen. Sebab, peran guru/dosen saat ini makin tersaingi dengan keberadaan beragam alat komunikasi, internet dengan media sosialnya dan televisi. Internet dan televisi sebetulnya merupakan alternatif sumber belajar. Namun, pada kenyataannya, Internet dan televisi menggeser peran guru/dosen sebagai penyampai ilmu. Internet dalam wadah TIK merupakan sumber yang luas untuk belajar. Internet memiliki potensi dan manfaat yang besar jika bisa dioptimalkannya dengan baik. Internet bisa menjadi sarana menambah ilmu dan wawasan pengetahuan. Internet juga menjadi sarana komunikasi yang cepat dan murah melalui beragam situs jejaring sosial seperti twitter dan Facebook. Jika guru/dosen tidak memutakhirkan dirinya terhadap perkembangan TIK, maka mereka bisa tersaingi dengan media sosial tersebut.
Berdasarkan banyak penelitian dan kajian ilmiah, penggunaan teknologi dalam pendidikan terutama TIK bisa meningkatkan kreativitas dan motivasi peserta didik. Jadi pendidik perlu memanfaatkan TIK dalam pembelajaran untuk mendapatkan manfaat positifnya dalam pendidikan bukan dampak negatifnya saja.

Disamping hal tersebut, Kasali (2013) dalam sosialisasi kurikulum 2013 menyampaikan tentang "Tantangan Indonesia dalam Abad ke 21", menyatakan ada 6 Pendorong Utama Teknologi Pendidikan harus diperhatikan, yaitu:

1. Mobile Learning, orang berharap untuk dapat bekerja dan belajar kapan pun dan dimana pun yang mereka inginkan.

2. Cloud Computing, kami menginginkan informasi agar dapat diakses di perangkat manapun.

3. Collaborative Learning. Dunia Semakin collaborative, mendorong perubahan dengan cara proyek siswa yang terstruktur. 
4. Mentoring. Karena Informasi dimana-mana, kualitas mentoring yang akan membuat perbedaan.

5. Hybrid Learning. Hybrid Learning Models (Tatap muka + Online), atau blended learning models dapat memanfaatkan kemampuan siswa secara online dimana telah dikembangkan secara independen dari sistem akademisi

6. Student Centered, pergeseran dari pendidikan yang berpusat kepada guru menjadi berpusat kepada siswa dan melibatkan mereka dengan menghubungkan kurikulum dengan kehidupan nyata para siswa.

Selanjutnya Kasali (2013) juga menyatakan ada 5 Tantangan Pendidikan Tinggi, yaitu:

1. Model-model pendidikan baru yang membawa kompetisi yang belum pernah terjadi sebelumnya dari model-model yang tradisional.

2. Bentuk baru dalam penerbitan dan penelitian yang belum dipahami dengan baik oleh pengambil keputusan.

3. Kita Jauh dari melihat literasi media digital sebagai norma yang diharapkan untuk profesional akademik.

4. Eksperimen dengan aplikasi teknologi yang inovatif sering dianggap sebagai peran luar dari seorang peneliti.

5. Di dalam dunia Open Source, perpustakaan berada di bawah tekanan untuk mengembangi cara-cara baru untuk mendukung beasiswa.

Enam pendorong utama penggunaan teknologi pendidikan dan lima tantangan pendidikan tinggi yang dikemukakan Kasali di atas berkaitan dengan 3 literasi, yaitu literasi informasi, media dan TIK. 3 literasi ini merupakan bagian dari keterampilan abad 21. OECD (2006) dan Menteri Pendidikan Muhammad Nuh (2013) me- nyatakan bahwa lingkungan belajar untuk tercapainya kompetensi abad 21 haruslah:

- Menciptakan latihan pembelajaran, dengan dukungan SDM dan infrastruktur.

- Memungkinkan pendidik untuk berkolaborasi, berbagi pengalaman dan integrasinya di kelas.

- Memungkinkan peserta didik untuk belajar yang relevan dengan konteks dunia.

- Mendukung perluasan keterlibatan komunitas dalam pembelajaran, baik langsung maupun online.

Sejalan dengan hal ini, Herawati (2011: 4) juga mengemukakan bahwa pengembangan kompetensi guru abad 21 terkait dengan teknologi, pedagogi, dan isi pembelajaran yang dibelajarkan atau Technological, Pedagogical, and Content Knowledge (TPACK). Guru/dosen perlu terus menerus meningkatkan pengetahuan dan keterampilannya membelajarkan siswa dan mahasiswanya dalam kerangka pikir TPCAK agar dapat membelajarkan siswa dan mahasiswanya secara efektif. Oleh karena itu guru/dosen perlu terus belajar sepanjang hayat agar dapat meningkatkan layanannya terhadap siswa dan mahasiswa yang dipercayakan kepadanya untuk dibelajarkan.

Penerapan MBL sangat sesuai untuk menghadapi Tantangan Indonesia dalam Abad ke 21 yang dikemukakan Kasali dengan 5 tantangan pendidikan tinggi dan 6 Pendorong Utama Teknologi dalam Pendidikan. MBL juga menyiapkan lingkungan belajar untuk tercapainya kompetensi abad 21 seperti yang dikemukakan OECD dan Menteri Pendidikan Muhammad Nuh.

MBL sangat tepat jika diterapkan pada lembaga Pendidikan tinggi LPTK. Sejalan dengan Herawati, Bintoro (2014) menyatakan LPTK sebagai lembaga pendidikan tinggi yang mengemban misi untuk menghasilkan calon pendidik yang 
unggul di abad 21. Calon pendidik unggul adalah pendidik yang dapat melaksanakan tugas pembelajaran dan pendidikan yang ditandai dengan kemampuan melaksanakan tugas pembelajaran aktif, inovatif, dan menyenangkan atau active learning in school (ALIS), harus disiapkan melalui suatu sistem pendidikan yang bermutu. Proses pendidikan calon pendidik di LPTK harus dirancang dan dikembangkan berdasarkan prinsip active learning in higher education (ALIHE) atau student active learning (SAL). Proses pembelajaran diarahkan pada upaya untuk mengaktifkan peserta didik, bukan dalam arti fisik melainkan dalam keseluruhan perilaku belajar. Keaktifan ini dapat diwujudkan antara lain melalui pemberian kesempatan menyatakan gagasan, mencari informasi dari berbagai sumber dan melaksanakan tugas-tugas yang merupakan aplikasi dari konsep-konsep yang telah dipelajari.

Menghadapi tantangan ini, LPTK sebagai penghasil calon pendidik/guru perlu membekali guru dan calon guru untuk terampil menggunakan teknologi terutama TIK, karena tantangan guru masa depan berkaitan dengan TIK. Guru harus mempunyai kemampuan pedagogi, penguasaan teknologi dan materi dalam proses pembelajarannya. Untuk itu perkuliahan di LPTK perlu membiasakan mahasiswanya menggunakan TIK. Direktur Diktis, Prof. Dr. Dede Rosyada (Berita Diktis: 2014) juga menyatakan bahwa sistem pembelajaran konvensional (faculty teaching) yang selama ini dilakukan kental dengan suasana instruksional dan kurang sesuai dengan dinamika perkembangan iptek yang sangat pesat. Disamping sistem pembelajaran yang masih konvensional, ternyata lulusan PTAI dirasa masih kurang memiliki penguasaan pengetahuan dan teknologi terbaru. Untuk menjawab permasalahan tersebut perlu pembelajaran berbasis e-learning untuk meningkatkan kualitas pembelajaran di PTAI.

Senada dengan pernyataan Direktur Diktis, Riduan Zain (Berita Diktis:2014) mengatakan bahwa implementasi e-learning di PT dimaksudkan sebagai inovasi pendidikan yang selalu mengakomodir perubahan sosial, dalam hal ini penggunaan IT, bukan hanya IT sebagai teknologi tetapi IT sebagai media pembelajaran e-learning. Kegemaran peserta didik pada IT tidak bisa dicegah, tetapi bagaimana pendidik mengakomodir kegemaran tersebut ke dalam mata kuliah, sehingga akan disukai oleh peserta didik.

Berkaitan dengan penjelasan di atas, jelaslah tantangan guru masa depan berkaitan dengan TIK. Seperti yang dinyatakan oleh Eggen dan Kauchak (2012: 27-28) bahwa standar untuk sekolah abad 21 atau abad digital untuk guru dan siswa berkaitan dengan penerapan teknologi dalam pembelajaran. Maka, guru/dosen harus bisa mempersiapkan siswanya untuk hidup di abad digital, salah satunya menggunakan pengetahuan mereka tentang materi pelajaran, pembelajaran dan teknologi untuk memfasilitasi pengalaman yang dipelajari siswa tingkat lanjut, kreativitas, dan inovasi dalam situasi tatap muka dan virtual melalui penerapan MBL dalam pembelajaran.

\section{PENUTUP}

MBL merupakan salah satu isu pendidikan terbaru dalam perkembangan globalisasi dan teknologi, yang menggabungkan pembelajaran tradisional tatap muka dan pembelajaran online ( $e$ learning). MBL merupakan salah satu cara baru untuk meningkatkan proses belajar dan pembelajaran. Menghadirkan pembelajaran sepanjang waktu adalah sebuah potensi, peluang dan tantangan 
dalam pembelajaran. Penerapan MBL sangat sesuai untuk menghadapi tantangan Indonesia dalam Abad ke 21 dan menyiapkan lingkungan belajar untuk tercapainya kompetensi abad 21 seperti yang dikemukakan OECD dan Menteri Pendidikan Muhammad Nuh. MBL juga sangat tepat jika diterapkan

\section{DAFTAR RUJUKAN}

Berita Diktis. 2014. Direktur Diktis Sorot Elearning untuk Peneingkatan Kualitas Pembelajaran di PTAI. http: //diktis.kemenag.go.id. Diakses 2 Juli 2014.

Bintoro, Totok. 2014. Pengembangan Kurikulum LPTK \& Kaitannya dengan KKNI. Makalah disampaikan pada lokakarya Desain Kurikulum LPTK Berkelanjutan PPG dengan Mengacu KKI di Universitas Muhamasiyah Sirakarta, 10 April 2014.

Comey. W.L. 2009. Blended Learning and the Classroom Environment: A Comparative Analysis of Students' Perception of the Classroom Environment across Community College Courses Taught in Traditional Face-to-face, Online and Blended Methods. (Disertation). The Faculty of The Graduate School of Education and Human Development of The George Washington University in partial fulfillment of the requirements for the degree of Doctor of Education

Dewey, J. (1938). Experience and education. New York: Collier MacMillan.

Discoll, M. 2002. Blended Learning: Let's Get Beyond the Hype.

Eggen. Paul., dan Kauchak. Don. 2012. Strategi dan Model Pembelajaran, Mengajarkan Konten dan Kete- pada lembaga Pendidikan tinggi LPTK, karena tantangan pengembangan kompetensi guru abad 21 terkait dengan teknologi, pedagogi, dan isi pembelajaran yang dibelajarkan atau Technological, Pedagogical, and Content Knowledge (TPACK).

rampilan Berpikir. Edisi 6. Jakarta: Indeks.

Graham, C.R. 2005. Blended Learning System. Definisi, Current, and Future Directions. dalam The Hand Book of Blended Learning

Herawati. 2011. Blended Learning untuk Menyiapkan Siswa Hidup di Abad 21. Makalah Seminar Nasional 2011, Pengembangan Pembelajaran berbasis Blended Learning. Universitas Negeri Malang.

Horn, M. B \& Staker, H. 2011. The Rise of K-12 Blended Learning. Innosight Institute. Public Impact.

Joyce, B dan Weil, M. 1992. Models Of Teaching $\quad\left(4^{\text {th }} \quad\right.$ Edition $)$ Massachusetts: Allyn and Bacon Publisher.

Kasali, Rhenald. 2013. Tantangan Indonesia Dalam Abad ke21 (Mengapa Kita Harus Siap Berubah?). Disampaikan dalam sosialisasi kurikulum 2013. Penyegaran Nara Sumber Pelatihan Guru untuk Implementasi Kurikulum 2013. Jakarta, 26-28 Juni 2013.

Muhammad Nuh. 2013. Pengembangan Kurikulum 2013. Disampaikan dalam sosialisasi kurikulum 2013. Penyegaran Nara Sumber Pelatihan Guru untuk Implementasi Kurikulum 2013. Jakarta, 26-28 Juni 2013. 
OECD. 2006. 21st Century Learning Environments.

Rusman. 2011. Model-model Pembelajaran, Mengembangkan Profesionalisme Guru. Jakarta: Raja Grafindo Perkasa.

Rusman, Kurniawan, D., Riyana, C. 2011. Pembelajaran Berbasis Teknologi Informasi dan Komunikasi. Mengembangkan Profesionalisme Guru. Jakarta: Raja Grafindo Perkasa.

Saikaew, K.R. Krutkam, W. Pattaramanon, R. Leelathakul, N., Chaipah, K., Chaosakul. (..) Using Facebook As A Supplementary
Tool For Teaching and Leraning. Thailand.

Silberman, Melvin L. 2006. Active Learning, 101 cara belajar siswa aktif. Bandung: Nusamedia.

Sukarno. (...). Blended Learning Sebuah Alternatif Model Pembelajaran Mahasiswa Program Sarjana (S-1) Kependidikan Bagi Guru Dalam Jabatan. Program PGSD FKIP Universitas Sebelas Maret Surakarta.

Trianto. 2010. Model Pembelajaran Terpadu, Konsep, Strategi, dan Implementasinya dalam Kurikulum Tingkat Satuan Pendidikan (KTSP). Kajarta: Bina Aksara. 